\title{
A NEW SPECIES OF MILLETTIA (LEGUMINOSAE-PAPILIONOIDEAE) FROM WEST AFRICA
}

\author{
CAREL C.H. JONGKIND \\ Nationaal Herbarium Nederland, Wageningen University branch (Herbarium Vadense), \\ Generaal Foulkesweg 37, 6703 BL Wageningen, The Netherlands \\ e-mail: Carel.Jongkind@wur.nl
}

\begin{abstract}
SUMMARY
Millettia liberica Jongkind (Leguminosae-Papilionoideae) from the forests of western Africa is described and illustrated.
\end{abstract}

Key words: Leguminosae-Papilionoideae, Millettia, Côte d'Ivoire, Liberia, Sierra Leone.

While going through literature and herbarium collections from West Africa for the ECOSYN Project (a research project on plant biodiversity and management of West African forests) we have identified several species new to science. One of these is the species described below.

The characters of the fruits (long, flat and woody), flowers (calyx equally toothed, stamens all but one united) and leaves (pinnate, conspicuous stipels) point clearly to Millettia. This genus is, surely for W and C Africa, in need of revision, especially the lianas are often not easy or even impossible to identify. The Millettia trees and shrubs from this area, however, can usually be identified without problem. This does not mean that misidentifications do not occur. While going through the herbarium specimens of M. sanagana Harms from W Africa, several specimens of the new species were found. In the Flora of W Tropical Africa (Hepper, 1958: 524) these specimens indeed key out as $M$. sanagana, mainly because of the conspicuous stipels and the densely hairy standard petal. Real specimens of M. sanagana cannot be keyed out with Hepper's key because they lack conspicuous stipels and have 3 to 6 pairs of leaflets. The description of M. sanagana by Pellegrin (1948: 227) is better, he describes leaves with 3 to 5 pairs of leaflets without stipules, which comes closer to reality and does fit the type specimen of the species. Millettia sanagana and M. liberica both share a densely hairy standard, but the dense appressed indumentum on the outside of the standard in M. liberica Jongkind is present in the upper half only, while the standard is completely hairy on the outside in M. sanagana. The shape of the leaflets of the two species is clearly different as well, the leaflets of $M$. sanagana are more stretched and less glossy than those of $M$. liberica. The combination of a truncate calyx, the standard with dense appressed indumentum only in the upper half, the almost glabrous fruits, and the number and shape of the leaflets, makes the new species clearly different from all other species in 
$\mathrm{W}$ and C Africa. Millettia sanagana and M. liberica belong to section Seriacanthae Dunn (Dunn, 1912: 134, 137, 138).

A key to all Millettia species from W Africa will be given in the soon to be published Guide to the Woody Plants of western African forests (W.D. Hawthorne \& C.C.H. Jongkind, in press).

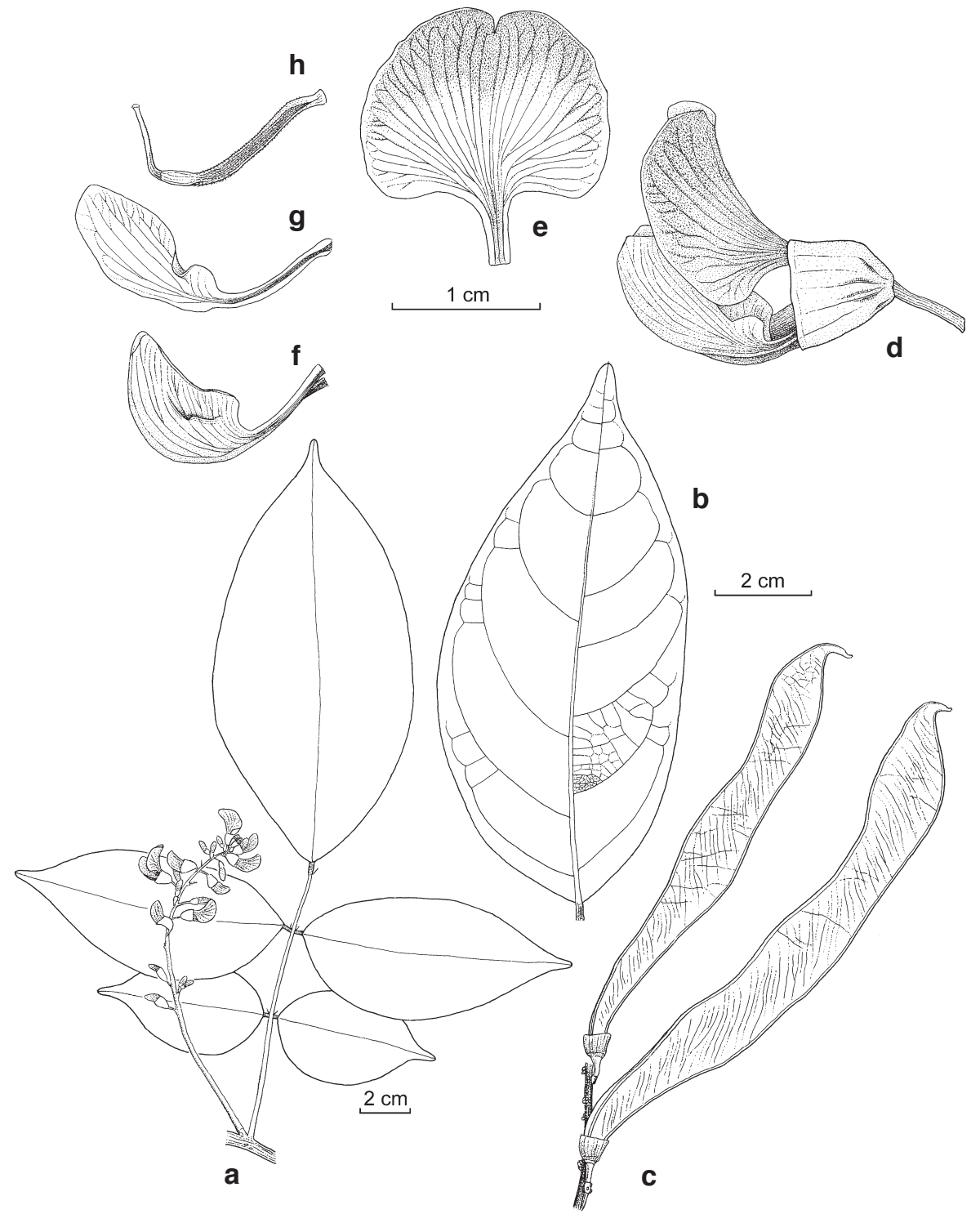

Fig. 1. Millettia liberica Jongkind. a. Branch with flowers; b. leaflet; c. pods; d. flower; e. flag from the outside; f. keel; g. wing; h. style (a, b: De Koning 6005; c-h: Beentje 880). 
Millettia liberica Jongkind, spec. nov. — Fig. 1

Arbuscula vel arbor ad $10 \mathrm{~m}$ alta. Folia imparipinnata 2- vel 3-jugata. Folioli elliptica, glabra. Pseudo-racemi axillares. Calyx dentium inconspicuorum. Legumina applata, glabra. Millettia sanagana Harms affinis. - Typus: Beentje 880 (holo WAG; iso BR, K, MO, P), Côte d'Ivoire, 10 km ESE of Taï, 6 Sept. 1975, fl. \& fr.

Shrub or tree up to $10 \mathrm{~m}$ tall. Stipules early caducous. Leaves with 2 or 3 pairs of leaflets, up to $35 \mathrm{~cm}$ long. Petiole up to $8 \mathrm{~cm}$ long, glabrous; rachis glabrous. Leaflets elliptic or ovate, both sides glossy and glabrous, midrib and lateral veins raised above, apex acuminate; terminal leaflet up to $18 \mathrm{~cm}$ long and $8.5 \mathrm{~cm}$ wide, with 5-7 pairs of lateral veins; petiolules puberulous; stipels 3-4 mm long, filiform. Pseudo-racemes up to $22 \mathrm{~cm}$ long, in the leaf axils near the end of the branchlets. Calyx campanulate and at most very shallowly lobed, $6 \mathrm{~mm}$ long and $4 \mathrm{~mm}$ wide, short appressed hairy, (partly) reddish or purple. Petals lilac or purple. Standard c. $17 \mathrm{~mm}$ long and wide (when flattened), with closed whitish appressed indumentum in upper half on the outside. Wings about as long as the standard and c. $6 \mathrm{~mm}$ wide, almost glabrous. Keel slightly shorter than standard and wings, glabrous or with a fringe of hairs along the apex. Stamens all but one united, free part 3-4 mm long. Ovary hairy; style glabrous. Pod flat and woody, with scattered appressed pale hairs to almost glabrous, up to $11 \mathrm{~cm}$ long and $1.7 \mathrm{~cm}$ wide, but maybe no full-grown pods collected yet.

Distribution - E Sierra Leone to W Côte d'Ivoire.

Habitat \& Ecology - Forest.

Note - The localities of the specimens from Côte d'Ivoire and Sierra Leone are close to the border with Liberia. The major part of the distribution area of the species lies within Liberia.

Additional specimens examined:

SiERRA LeONE: Deighton 2228 (K), Bobuabu, Koya Chiefdom, 22.9.1931; Deighton 2254 (K), Mattru, 1931; Deighton 2857 (K), Makeni, 14.1.1934; N.W. Thomas 3261(K), Bumbuna, 20.10.1914; N.W. Thomas 7033 (K), Kumrabai, 31.12.1914.

Liberia: Baldwin 10627 (K), Kle, near St. Paul River, 10.12.1947; Blyden 889 (BR, K, WAG), Tapitta, along the road, 21.7.1969; J.W.A. Jansen 807 (BR, P, WAG), Chien, 4.10.1969; J.W.A. Jansen 814 (BR, WAG), $10 \mathrm{ml}$ E of Tapita, near the river, along the road to Chien, 15.7.1968; J.W.A. Jansen 2103 (BR, WAG), $10 \mathrm{ml} \mathrm{NW}$ of Tchien, swampy area, 22.7.1970.

CôTE D'IvorRE: Aké Assi 10151 (G), route de Tabou, entre Sakré et Nigré, 23.5.1968; Aké Assi 14833 (G), entre Taï et Sakré, Troy, 29.8.1979; De Koning 6005 (BR, K, WAG), Taï, 11.9.1975.

\section{ACKNOWLEDGEMENTS}

The work resulting in this publication was carried out in the context of the ECOSYN project, a research project on plant biodiversity and management of West African forests. This project is funded by the European Community (CEC-DG Development Action Plan). I am grateful to Frits Adema for his comments on the manuscript and Marjolein Spitteler for preparing the illustration.

\section{REFERENCES}

Dunn, S.T. 1912. A review of the genus Millettia Wight et Arn. J. Linn. Soc. Bot. 41: 123-243.

Hepper, F.N. 1958. Papilionaceae. In: R.W.J. Keay, Flora of W Tropical Africa, second edition, part

1, 2: 524-527. Crown Agents for Overseas Governments and Administrations, London. Pellegrin, F. 1948. Les Légumineuses du Gabon. Librairie Larose, Paris. 